\title{
CREATIVE INDUSTRIES IN THE POLISH ECONOMY
}

\author{
RAFAE KASPRZAK \\ Institute of Management, Warsaw School of Economics, Poland \\ Manuscript received: October 2, 2014 \\ Revised version: March 30, 2015
}

\begin{abstract}
KasprzaK R., 2015. Creative industries in the Polish economy. Quaestiones Geographicae 34(2), Bogucki Wydawnictwo Naukowe, Poznań, pp. 35-43, 7 tables. DOI 10.1515/quageo-2015-0013, ISSN 0137-477X.

AвSTRACт: The paper presents changes in the number of entities in the creative sector in Polish regions between 2009 and 2013. In the analysis use was made of Poland's Central Statistical Office data to describe the development rate of this sector in the regions.

KEY WORDS: creative industries, regional development, regions, Poland

Rafat Kasprzak, Institute of Management, Warsaw School of Economics, Madalińskiego 6/8, room 319, 02-554 Warsaw, Poland; e-mail: rafal.kasprzak@sgh.waw.pl
\end{abstract}

\section{Introduction}

The creative sector in the Polish economy seems to be both a 'new' and an 'old' part of the socio-economic system. Economic activities related with the absorption of human creativity have been present for many decades; worth mentioning, for example, are the international successes of Polish film-makers, designers, authors, or poets, not only under the centrally planned economy but also in the recent years. Today this sector of the economy has come to be perceived as an interesting opportunity for regional development, which makes it more and more visible in local and regional growth strategies. In the majority of strategic documents, the creative sector is often described as a sector with a significant positive impact on both, sustainable economic growth and the quality of life.

\section{Definitions of the creative sector}

An attempt to estimate the number of entities in the creative sector and their impact on the local economy requires, first, the development of an effective definition which not only allows specifying them, but also counting their number. This seems to be very difficult, however. In scientific sources, two methodologies can be identified which help to formulate a few significant definitions of the creative sector. One focuses on the product manufactured and its feature which is assigned an intellectual property right. It means that the core of creative industries manufacture products protected by copyright. The other approach focuses on the nature of the manufacturing process itself, assuming that it should involve human creativity in the act of creation. It means that creative industries manufacture products requiring a significant level of creative activity. Those two methodologies have worked out a few interesting definitions of the analysed economic sector.

It seems that the definition most commonly used in Poland is that proposed by Great Britain's Department for Culture, Media and Sport (2001), which describes cultural industries as those activities which have their origin in individual creativity, skill and talent, with a potential for job and wealth creation through the generation and 
exploitation of intellectual property, which is a specific feature of the product that is their outcome. This definition also describes individual areas of activity belonging to this sector, so it is possible to carry out analyses of its impact on the economy and to make comparative studies of regions and states.

Another approach to this type of activity in the economic system involves the concept of 'leisure industries', which comprises the segment of business focused on the organisation of households' leisure time. Leisure industries include activities people perform during leisure time, thus also creating time-consumption markets, i.e. those organising the way they spend their leisure time (Bombol 2008: 113). Leisure industries are an important sector of the economy as they comprise markets for cultural, tourist and sport services. This is a wider concept than the term 'creative industries' and is often used by regional authorities (Urzad ... 2013).

An interesting example of the treatment of an activity inspired by culture is also the term 'spectacle industries' or 'experience industries' (Debord 1967), which comprises a wider group of economic activities than that of creative industries. Experience industries are defined as a sector combining both, activities in the sphere of culture and those that use or are inspired by products of culture. An important factor facilitating the development of experience industries is the growth of tourism, and the key feature characterising this sector is readiness to produce and deliver a unique experience connected with the process of the consumption of its products by the consumer. Therefore, experience industries comprise both, creative industries and leisure industries (Segers, Huijgh 2006: 13).

The definition adopted by the World Intellectual Property Organization, in turn, tends to focus on the nature of the final product rather than on the activity of an entity and defines this area as 'copyright industries'. The key factor qualifying an economic activity for this sector is the fact that its products are protected by copyright.

The definition proposed by the United Nations for the purposes of cultural statistics describes creative industries as (UNCAD 2010: 8):

- the sector of the production and distribution of goods and services for which the main production factor is creativity and intellectual capital;
- the area of economic activity focusing on (but not restricted to) arts, enabling the generation of revenues from trade in both, products of culture and copyrights;

- the sector which includes tangible products and their intangible aspects as well as market activity and economic calculus; and

- the sector located between arts, artists, services and other industrial sectors, which contributes to the development of a new sector in international trade.

In this definition, four sectors of creative industries are distinguished which include: the spiritual and the tangible cultural heritage, arts, media, and functional creation.

Working out an explicit definition is hindered by the very dynamic development of this sector as well as a quick absorption of technological innovation which not only alters production processes but also causes a diversification of distribution methods. This greatly amplifies the still serious confusion with the definition of this area. Finding a stiff definition framework for the creative sector is, therefore, a big academic challenge.

In the systematics of services (Dąbrowska 2008: 29), the scope of activity of creative industries can be described as embracing functions related to the organisation of a household's leisure time, or services of an intangible nature comprising consumption and general social actions. The services meet the needs connected with the development of human capital and leisure. To a certain degree, they have the nature of social services (Janoś-Kresło 2002: 17) since some activities focus on an individual recipient and are financed mainly from public means. They can be treated as social services because the human being is their specific object of direct impact; an impact whose objective is to form his intellectual and physical potential through knowledge, skills and a better frame of mind.

The above definitions of the creative sector have a certain feature in common: they speak of an economic activity that focuses on the production of cultural goods. Therefore, it is very difficult to develop a coherent and explicit definition of this sector that, on the one hand, would present its diversity, and on the other, that would determine the limits of analysis. This undoubtedly follows from the indeterminacy of the terms 'culture' and 'creativity', and from the specificity of 
cultural products in which their symbolic content intertwines with their physical carrier determining the way of their distribution. Therefore, one may note that creative industries are activities involving not only the creation of new symbols but also their marketing. This means that the task of creative industries is, first, to create and commercialise products of culture and, secondly, to place them on the market. Such an approach requires clarifying two issues.

The first is the goal of commercialisation. Obviously, the basic one is to maximise profits. In this sense, the creative sector can be described as a group of enterprises manufacturing and placing products of culture on the market and seeking to generate profits. However, this approach does not fully account for the sector's specificity. A manufacturer of cultural goods may have other objectives than profit maximisation; for example, it can be the maximisation of cultural value, which definitely requires other measures (Throsby 2001: 13). Therefore, it seems reasonable to expand the creative sector to include those entities that carry out their activity with aims other than profit maximisation, i.e. a wide group of non-profit entities. They may have various organisational forms, like associations, foundations or cultural institutions. The sector of creative industries is, therefore, a set of entities differing in their organisational forms and goals of economic activity, but having a common denominator: creating and marketing cultural products.

The second issue which requires clarifying is the scope of activity of the creative sector. The presented definitions indicate that its key task is to produce and process products of culture. Since the creative sector has earlier been described as the types of economic activity whose task is to place cultural products on the market, we can say that it includes organisations which produce physical carriers of cultural products as well as technological solutions enabling their delivery. In turn, products manufactured in order to enable the consumption of - only and exclusively - cultural products belong to the type of activity supporting the sector of creative industries.

Hence, in trying to define this sector in the realities of the Polish economy, one can describe it as a sphere of social services embracing economic activities devoted to the creation and commercialisation of products of culture that take various organisational business forms in the following sub-sectors:

- arts and crafts, comprising visual arts, performing arts, and the national heritage, libraries and archives;

- creative production, comprising programming, publishing, film and TV production, as well as radio and music production; and

- creative services, comprising fashion and design, advertising and related activity, as well as architecture and interior design.

\section{Development of the creative sector in Poland}

The sector of creative industries includes three sub-sectors where we can distinguish several areas that are assigned relevant codes in the economic activity classification (PKD in Poland, corresponding to NACE) (Table 1).

Table 1. Creative industries - division and classification according to PKD 2007 (NACE Rev. 2).

\begin{tabular}{|c|c|c|}
\hline \multirow{10}{*}{ 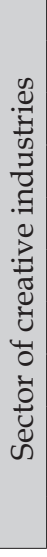 } & \multirow[t]{3}{*}{ Sub-sector of arts and crafts } & Visual arts (74.20.Z; 90.03.Z; 47.78.Z) \\
\hline & & Performing arts (90.01.Z; 90.02.Z; 90.04.Z) \\
\hline & & National heritage, libraries and archives (91.01.A; 91.01.B; 91.02.Z) \\
\hline & \multirow[t]{4}{*}{ Sub-sector of creative production } & Programming (58.21.Z) \\
\hline & & Publishing (58.11.Z, 58.13.Z; 58.14.Z; 58.19.Z) \\
\hline & & Film and TV production (59.11.Z; 59.13.Z; 59.14.Z) \\
\hline & & Radio and music production (59.20.Z; 60.10.Z; 60.20.Z) \\
\hline & \multirow[t]{3}{*}{ Sub-sector of creative services } & Fashion and design (74.10.Z) \\
\hline & & $\begin{array}{c}\text { Advertising and related activity (73.11.Z; } 73 \text { Dec. A; } 73 \text { Dec. B; } 73 \text { Dec. C; } 73 \\
\text { Dec. D) }\end{array}$ \\
\hline & & Architecture and interior design (71.11.Z) \\
\hline
\end{tabular}


Table 2. Number of entities of the creative sector entered into the REGON register in the years 2009-2013.

\begin{tabular}{|c|c|c|c|c|c|c|c|c|c|}
\hline Area/status at & $\begin{array}{c}31 \text { Dec. } \\
2009\end{array}$ & $\begin{array}{l}30 \text { June } \\
2010\end{array}$ & $\begin{array}{c}31 \text { Dec. } \\
2010\end{array}$ & $\begin{array}{c}30 \text { June } \\
2011\end{array}$ & $\begin{array}{c}31 \text { Dec. } \\
2011\end{array}$ & $\begin{array}{c}30 \text { June } \\
2012\end{array}$ & $\begin{array}{c}31 \text { Dec. } \\
2012\end{array}$ & $\begin{array}{l}30 \text { June } \\
2013\end{array}$ & $\begin{array}{c}31 \text { Dec. } \\
2013\end{array}$ \\
\hline Poland & 135,339 & 140,274 & 144,042 & 144,087 & 141,797 & 141,735 & 141,875 & 143,385 & 144,236 \\
\hline \multicolumn{10}{|c|}{ Voivodeship } \\
\hline Lower Silesia & 10,000 & 10,453 & 10,776 & 10,888 & 10,866 & 10,896 & 10,983 & 11,002 & 11,054 \\
\hline Kujavia-Pomerania & 5,663 & 5,771 & 5,851 & 5,862 & 5,747 & 5,741 & 5,691 & 5,735 & 5,807 \\
\hline Lublin & 5,252 & 5,426 & 5,483 & 5,425 & 5,216 & 5,225 & 5,139 & 5,293 & 5,283 \\
\hline Lubuska Land & 2930 & 3,036 & 3,086 & 3,061 & 2,956 & 2,947 & 2,885 & 2,862 & 2,852 \\
\hline Łódź & 7,673 & 7,952 & 8,307 & 8,265 & 8,114 & 8,204 & 8,171 & 8,258 & 8,216 \\
\hline Małopolska & 12,015 & 12,601 & 13,002 & 13,185 & 13,029 & 13,051 & 13,116 & 13,244 & 13,219 \\
\hline Mazovia & 34,481 & 35,567 & 36,289 & 36,028 & 36,015 & 35,991 & 36,384 & 36,759 & 37,456 \\
\hline Opole & 3,259 & 3,369 & 3,510 & 3,448 & 3,321 & 3,240 & 3,182 & 3,260 & 3,214 \\
\hline Subcarpat & 4,096 & 4,350 & 4,523 & 4,637 & 4,481 & 4,527 & 4,458 & 4,554 & 4,580 \\
\hline Podlasie & 2,827 & 2,898 & 2,976 & 3,042 & 2,995 & 3,021 & 2,987 & 3,040 & 2,981 \\
\hline Pomerania & 7,902 & 8,232 & 8,416 & 8,457 & 8,266 & 8,275 & 8,249 & 8,356 & 8,422 \\
\hline Silesia & 14,122 & 14,725 & 15,331 & 15,267 & 14,891 & 14,841 & 14,832 & 14,936 & 14,977 \\
\hline Świętokrzyska Land & 3,054 & 3,148 & 3,199 & 3,213 & 3,095 & 3,080 & 3,082 & 3,101 & 3,036 \\
\hline Warmia-Mazuria & 3,226 & 3,367 & 3,449 & 3,458 & 3,302 & 3,274 & 3,245 & 3,310 & 3,299 \\
\hline Wielkopolska & 12,627 & 12,930 & 13,316 & 13,293 & 13,229 & 13,255 & 13,409 & 13,541 & 13,688 \\
\hline West Pomerania & 6,212 & 6,449 & 6,528 & 6,558 & 6,274 & 6,167 & 6,062 & 6,134 & 6,152 \\
\hline
\end{tabular}

Source: REGON data.

The above classification allows an analysis of the development of this sector in Poland in the years 2009-2013 using the information about the number of entities registered in the REGON (National Business Register Number) base. The analysis was carried out on the basis of the REGON register data kept by the Central Statistical Office and the status of national economic entities entered into the register on 31 Dec. 2009, 30 June 2010, 31 Dec. 2010, 30 June 2011, 31 Dec. 2011, 30 June 2012, 31 Dec. 2012, 30 June 2013, and 31 Dec. 2013.

To make a survey of the structure of national economic entities registered in the REGON register, one should be aware of several factors characterising it. The REGON register was set up pursuant to Art. 41, paragraph 1, point 1 of the Public Statistics Act of 29 June 1995 (Dziennik ... 2012). It is a regularly updated set of information on national economic entities run in the IT system in the form of a central database and local databases. It enables making a list of addresses of operating entities, and it can serve to set up databases and data banks concerning national economic units.

However, it is worth noting that despite the wide scope of data and the fact that it includes all entities of the national economy irrespective of their organisational form, the register has a few weaknesses. First of all, it is the mo- ment of entering the data into the register. For the majority of enterprises doing business, this is the time of their initial registration, whereas later updates, if necessary, are relatively seldom. Its next drawback is the registration of entities which, while figuring in the database, may not conduct business actively. Also, the REGON register does not answer questions about the actual area where business is conducted because it only provides the address of the headquarters of an entity or its plants, usually declared during registration. And a list of entities assembled by their PKD (NACE) code does not mean that they actually carry out the activity denoted by it. Despite these weaknesses, it is the only nation-wide database which enables an initial identification of the number of entities in the individual sectors of the economy.

The number of entities of the sector of creative industries entered into the REGON register in the years 2009-2013 is presented in Table 2.

In the period under analysis, the average rate of change in the number of entities of the creative sector entered into the REGON register was $+0.80 \%$ and differed in individual voivodeships (regions). Those where their number grew included: Subcarpathia (an average growth rate of $+1.41 \%)$, Lower Silesia $(+1.26 \%)$, Małopolska $(+1.20 \%)$, Mazovia $(+1.04 \%)$, and Wielkopolska $(+1.01 \%)$. In turn, a fall in the number of en- 
Table 3. Poviats with the biggest number of entities of the creative sector in Poland in the years 2009-2013.

\begin{tabular}{|l|c|c|c|c|c|c|c|c|c|}
\hline \multicolumn{1}{|c|}{ Poviat/ status at } & $\begin{array}{c}31 \text { Dec. } \\
2009\end{array}$ & $\begin{array}{c}30 \text { June } \\
2010\end{array}$ & $\begin{array}{c}31 \text { Dec. } \\
2010\end{array}$ & $\begin{array}{c}30 \text { June } \\
2011\end{array}$ & $\begin{array}{c}31 \text { Dec. } \\
2011\end{array}$ & $\begin{array}{c}30 \text { June } \\
2012\end{array}$ & $\begin{array}{c}31 \text { Dec. } \\
2012\end{array}$ & $\begin{array}{c}30 \text { June } \\
2013\end{array}$ & $\begin{array}{c}31 \text { Dec. } \\
2013\end{array}$ \\
\hline Capital city of Warsaw & 23,036 & 23,611 & 24,121 & 23,867 & 23,980 & 24,056 & 24,431 & 24,740 & 25,285 \\
\hline City of Cracow & 6,046 & 6,385 & 6,562 & 6,626 & 6,616 & 6,615 & 6,612 & 6,623 & 6,638 \\
\hline City of Poznań & 4,791 & 4,873 & 5,017 & 5,035 & 5,101 & 5,123 & 5,242 & 5,275 & 5,383 \\
\hline City of Wrocław & 4,509 & 4,675 & 4,814 & 4,965 & 5,001 & 5,029 & 5,116 & 5,107 & 5,144 \\
\hline City of Łódź & 3,524 & 3,647 & 3,798 & 3,762 & 3,740 & 3,810 & 3,867 & 3,925 & 3,923 \\
\hline City of Gdańsk & 2,587 & 2,677 & 2,694 & 2,702 & 2,689 & 2,716 & 2,728 & 2,741 & 2,805 \\
\hline City of Szczecin & 2,538 & 2,635 & 2,712 & 2,714 & 2,642 & 2,567 & 2,551 & 2,542 & 2,581 \\
\hline City of Katowice & 1,753 & 1,833 & 1,898 & 1,905 & 1,918 & 1,937 & 1,934 & 1,964 & 1,973 \\
\hline City of Bydgoszcz & 1,708 & 1,753 & 1,766 & 1,757 & 1,717 & 1,681 & 1,679 & 1,675 & 1,696 \\
\hline City of Lublin & 1,666 & 1,702 & 1,737 & 1,721 & 1,680 & 1,661 & 1,634 & 1,650 & 1,651 \\
\hline
\end{tabular}

Source: REGON data.

tities was registered in Lubuska Land $(-0.34 \%)$, Opole $(-0.17 \%)$, West Pomerania $(-0.12 \%)$, and Świętokrzyska Land (-0.07\%).

The number of entities in this sector is highly diversified, the dominant position occupied by Mazovia, Silesia, Wielkopolska, Małopolska, and Lower Silesia. The differences are even greater when analysed by poviat (sub-voivodeship units). Those with the biggest number of entities of the creative sector entered into the REGON register are the capital city of Warsaw and the urban poviats presented in Table 3 .

As we can see, the number of those entities is greatly diversified in individual poviats. The capital city of Warsaw has the biggest number of entities of the creative sector; they accounted for from $17.02 \%$ of all entities registered at 31 Dec. 2009 to $17.53 \%$ of those registered at 31 Dec. 2013.

The creative sector consists of three sub-sectors. Changes in the number of entities in the arts and crafts sub-sector in the REGON register over the years 2009-2013 are presented in Table 4.

Over the study period, the average rate of change in the number of entities of the arts and crafts sub-sector entered into the REGON register was negative for both, their overall number $(-1.15 \%$ for the whole of Poland) and in individual regions. The biggest fall rates were noted in the voivodeships: Lubuska Land (-2.03\%), West

Table 4. Number of entities of the sub-sector of arts and crafts within the creative sector entered into the REGON register in the years 2009-2013.

\begin{tabular}{|l|r|r|r|r|r|r|r|r|r|r|}
\hline \multicolumn{1}{|c|}{ Area/ status at } & $\begin{array}{c}31 \text { Dec. } \\
2009\end{array}$ & $\begin{array}{c}30 \text { June } \\
2010\end{array}$ & $\begin{array}{c}31 \text { Dec. } \\
2010\end{array}$ & $\begin{array}{c}30 \text { June } \\
2011\end{array}$ & $\begin{array}{c}31 \text { Dec. } \\
2011\end{array}$ & $\begin{array}{c}\text { 30 June } \\
2012\end{array}$ & $\begin{array}{c}31 \text { Dec. } \\
2012\end{array}$ & $\begin{array}{c}30 \text { June } \\
2013\end{array}$ & $\begin{array}{c}31 \text { Dec. } \\
2013\end{array}$ \\
\hline Poland & 60,654 & 60,367 & 60,494 & 58,893 & 56,542 & 55,871 & 55,192 & 55,753 & 55,302 \\
\hline \multicolumn{7}{|c|}{ Voivodeship } \\
\hline Lower Silesia & 4,144 & 4,201 & 4,242 & 4,161 & 4,094 & 4,050 & 4,050 & 4,089 & 4,052 \\
\hline Kujavia-Pomerania & 2,842 & 2,784 & 2,785 & 2,716 & 2,619 & 2,578 & 2,547 & 2,566 & 2,589 \\
\hline Lublin & 3,002 & 2,976 & 2,946 & 2,860 & 2,708 & 2,700 & 2,630 & 2,702 & 2,674 \\
\hline Lubuska Land & 1,546 & 1,526 & 1,527 & 1,475 & 1,400 & 1,385 & 1,349 & 1,327 & 1,312 \\
\hline Łódź & 3,550 & 3,570 & 3,641 & 3,506 & 3,389 & 3,407 & 3,342 & 3,345 & 3,314 \\
\hline Małopolska & 5,143 & 5,108 & 5,156 & 5,075 & 4,874 & 4,822 & 4,801 & 4,857 & 4,806 \\
\hline Mazovia & 13,091 & 12,968 & 12,885 & 12,375 & 12,131 & 11,964 & 11,882 & 11,942 & 12,024 \\
\hline Opole & 1,836 & 1,834 & 1,857 & 1,794 & 1,707 & 1,635 & 1,600 & 1,633 & 1,609 \\
\hline Subcarpathia & 2,170 & 2,216 & 2,261 & 2,256 & 2,108 & 2,139 & 2,072 & 2,158 & 2,122 \\
\hline Podlasie & 1,397 & 1,348 & 1,350 & 1,335 & 1,280 & 1,306 & 1,274 & 1,299 & 1,253 \\
\hline Pomerania & 3,456 & 3,466 & 3,433 & 3,395 & 3,208 & 3,183 & 3,106 & 3,140 & 3,116 \\
\hline Silesia & 6,399 & 6,412 & 6,502 & 6,312 & 6,010 & 5,893 & 5,824 & 5,867 & 5,796 \\
\hline Świętokrzyska Land & 1,711 & 1,697 & 1,680 & 1,649 & 1,569 & 1,549 & 1,546 & 1,548 & 1,504 \\
\hline Warmia-Mazuria & 1,681 & 1,675 & 1,677 & 1,636 & 1,553 & 1,526 & 1,520 & 1,552 & 1,540 \\
\hline Wielkopolska & 5,628 & 5,497 & 5,508 & 5,363 & 5,124 & 5,012 & 5,014 & 5,032 & 4,946 \\
\hline West Pomerania & 3,058 & 3,089 & 3,044 & 2,985 & 2,768 & 2,722 & 2,635 & 2,696 & 2,645 \\
\hline
\end{tabular}

Source: REGON data. 
Table 5. Number of entities of the sub-sector of creative production within the creative sector entered into the REGON register in the years 2009-2013.

\begin{tabular}{|c|c|c|c|c|c|c|c|c|c|}
\hline Area/status at & $\begin{array}{c}31 \text { Dec. } \\
2009\end{array}$ & $\begin{array}{c}\text { 30 June } \\
2010\end{array}$ & $\begin{array}{c}31 \mathrm{Dec} . \\
2010\end{array}$ & $\begin{array}{c}30 \text { June } \\
2011\end{array}$ & $\begin{array}{c}31 \mathrm{Dec} . \\
2011\end{array}$ & $\begin{array}{c}\text { 30 June } \\
2012\end{array}$ & $\begin{array}{c}31 \text { Dec. } \\
2012\end{array}$ & $\begin{array}{c}30 \text { June } \\
2013\end{array}$ & $\begin{array}{c}31 \text { Dec. } \\
2013\end{array}$ \\
\hline Poland & 20,113 & 21,115 & 21,596 & 21,611 & 20,984 & 20,885 & 20,774 & 20,812 & 20,809 \\
\hline \multicolumn{10}{|c|}{ Voivodeship } \\
\hline Lower Silesia & 1,323 & 1,366 & 1,381 & 1,379 & 1,361 & 1,368 & 1,367 & 1,323 & 1,348 \\
\hline Kujavia-Pomerania & 844 & 870 & 842 & 822 & 806 & 792 & 769 & 777 & 761 \\
\hline Lublin & 638 & 682 & 671 & 667 & 616 & 617 & 604 & 628 & 616 \\
\hline Lubuska Land & 326 & 345 & 363 & 347 & 335 & 314 & 305 & 286 & 284 \\
\hline Łódź & 1,039 & 1,105 & 1,130 & 1,143 & 1,084 & 1,079 & 1,062 & 1,072 & 1,040 \\
\hline Małopolska & 1,708 & 1,839 & 1,882 & 1,902 & 1,844 & 1,841 & 1,827 & 1,843 & 1,813 \\
\hline Mazovia & 7,359 & 7,673 & 7,927 & 7,927 & 7,842 & 7,837 & 7,938 & 7,976 & 8,110 \\
\hline Opole & 360 & 373 & 390 & 380 & 360 & 354 & 341 & 351 & 346 \\
\hline Subcarpathia & 447 & 478 & 477 & 482 & 451 & 455 & 429 & 431 & 417 \\
\hline Podlasie & 330 & 339 & 350 & 352 & 335 & 340 & 325 & 326 & 311 \\
\hline Pomerania & 1,022 & 1,098 & 1,109 & 1,106 & 1,053 & 1,046 & 1,023 & 1,018 & 1,024 \\
\hline Silesia & 1,784 & 1,875 & 1,969 & 1,965 & 1,888 & 1,853 & 1,837 & 1,817 & 1,799 \\
\hline Świętokrzyska Land & 383 & 383 & 379 & 390 & 356 & 346 & 343 & 343 & 330 \\
\hline Warmia-Mazuria & 348 & 388 & 401 & 411 & 361 & 362 & 350 & 362 & 347 \\
\hline Wielkopolska & 1,491 & 1,560 & 1,577 & 1,571 & 1,577 & 1,572 & 1,572 & 1,587 & 1,609 \\
\hline West Pomerania & 711 & 741 & 748 & 767 & 715 & 709 & 682 & 672 & 654 \\
\hline
\end{tabular}

Source: REGON data.

Pomerania $(-1.80 \%)$ and Opole $(-1.64 \%)$. The lowest fall rates occurred in Subcarpathia, Lower Silesia $(-0.28 \%)$ and Małopolska $(-0.84 \%)$.

The second sub-sector is that of creative production. Table 5 shows changes in the REGON-registered number of entities in this sub-sector over the years 2009-2013.
In the period in question, the average rate of change in the number of entities of the creative production sub-sector entered into the REGON register in individual voivodeships differed. Those showing a rise were: Mazovia $(+1.22 \%)$, Wielkopolska $(+0.96 \%)$, Małopolska $(+0.75 \%)$, Lower Silesia $(+0.23 \%)$, Silesia $(+0.10 \%)$, Pomer-

Table 6. Number of entities of the sub-sector of creative services within the creative sector entered into the REGON register in the years 2009-2013.

\begin{tabular}{|l|r|r|r|r|r|r|r|r|r|r|}
\hline \multicolumn{1}{|c|}{ Area/ status at } & $\begin{array}{c}31 \text { Dec. } \\
2009\end{array}$ & $\begin{array}{c}30 \text { June } \\
2010\end{array}$ & $\begin{array}{c}31 \text { Dec. } \\
2010\end{array}$ & $\begin{array}{c}30 \text { June } \\
2011\end{array}$ & $\begin{array}{c}31 \text { Dec. } \\
2011\end{array}$ & $\begin{array}{c}30 \text { June } \\
2012\end{array}$ & $\begin{array}{c}31 \text { Dec. } \\
2012\end{array}$ & $\begin{array}{c}30 \text { June } \\
2013\end{array}$ & $\begin{array}{c}31 \text { Dec. } \\
2013\end{array}$ \\
\hline Poland & 54,572 & 58,792 & 61,952 & 63,583 & 64,271 & 64,979 & 65,909 & 66,820 & 68,125 \\
\hline \multicolumn{7}{|c|}{ Voivodeship } \\
\hline Lower Silesia & 4,533 & 4,886 & 5,153 & 5,348 & 5,411 & 5,478 & 5,566 & 5,590 & 5,654 \\
\hline Kujavia-Pomerania & 1,977 & 2,117 & 2,224 & 2,324 & 2,322 & 2,371 & 2,375 & 2,392 & 2,457 \\
\hline Lublin & 1,612 & 1,768 & 1,866 & 1,898 & 1,892 & 1,908 & 1,905 & 1,963 & 1,993 \\
\hline Lubuska Land & 1,058 & 1,165 & 1,196 & 1,239 & 1,221 & 1,248 & 1,231 & 1,249 & 1,256 \\
\hline Lódź & 3,084 & 3,277 & 3,536 & 3,616 & 3,641 & 3,718 & 3,767 & 3,841 & 3,862 \\
\hline Małopolska & 5,164 & 5,654 & 5,964 & 6,208 & 6,311 & 6,388 & 6,488 & 6,544 & 6,600 \\
\hline Mazovia & 14,031 & 14,926 & 15,477 & 15,726 & 16,042 & 16,190 & 16,564 & 16,841 & 17,322 \\
\hline Opole & 1,063 & 1,162 & 1,263 & 1,274 & 1,254 & 1,251 & 1,241 & 1,276 & 1,259 \\
\hline Subcarpathia & 1,479 & 1,656 & 1,785 & 1,899 & 1,922 & 1,933 & 1,957 & 1,965 & 2,041 \\
\hline Podlasie & 1,100 & 1,211 & 1,276 & 1,355 & 1,380 & 1,375 & 1,388 & 1,415 & 1,417 \\
\hline Pomerania & 3,424 & 3,668 & 3,874 & 3,956 & 4,005 & 4,046 & 4,120 & 4,198 & 4,282 \\
\hline Silesia & 5,939 & 6,438 & 6,860 & 6,990 & 6,993 & 7,095 & 7,171 & 7,252 & 7,382 \\
\hline Świętokrzyska Land & 960 & 1,068 & 1,140 & 1,174 & 1,170 & 1,185 & 1,193 & 1,210 & 1,202 \\
\hline Warmia-Mazuria & 1,197 & 1,304 & 1,371 & 1,411 & 1,388 & 1,386 & 1,375 & 1,396 & 1,412 \\
\hline Wielkopolska & 5,508 & 5,873 & 6,231 & 6,359 & 6,528 & 6,671 & 6,823 & 6,922 & 7,133 \\
\hline West Pomerania & 2,443 & 2,619 & 2,736 & 2,806 & 2,791 & 2,736 & 2,745 & 2,766 & 2,853 \\
\hline
\end{tabular}

Source: REGON data. 
Table 7. Number of entities of the creative sector in Poland by area of activity in the years 2009-2013.

\begin{tabular}{|c|c|c|c|c|c|c|c|c|c|}
\hline Status at & $\begin{array}{c}31 \text { Dec. } \\
2009\end{array}$ & $\begin{array}{c}30 \text { June } \\
2010\end{array}$ & $\begin{array}{c}31 \mathrm{Dec} . \\
2010\end{array}$ & $\begin{array}{c}30 \text { June } \\
2011\end{array}$ & \begin{tabular}{|c|}
31 Dec. \\
2011
\end{tabular} & $\begin{array}{c}30 \text { June } \\
2012\end{array}$ & $\begin{array}{c}31 \text { Dec. } \\
2012\end{array}$ & \begin{tabular}{|c|}
30 June \\
2013
\end{tabular} & $\begin{array}{c}31 \mathrm{Dec} . \\
2013\end{array}$ \\
\hline Sub-sector of arts and crafts & 60,654 & 60,367 & 60,494 & 58,893 & 56,542 & 55,871 & 55,192 & 55,753 & 55,302 \\
\hline Visual arts & 47,768 & 47,142 & 46,959 & 45,369 & 43,322 & 42,701 & 42,069 & 42,415 & 41,937 \\
\hline Performing arts & 9,824 & 10,154 & 10,475 & 10,480 & 10,199 & 10,134 & 10,075 & 10,268 & 10,292 \\
\hline $\begin{array}{l}\text { National heritage, libraries and } \\
\text { archives }\end{array}$ & 3,062 & 3,071 & 3,060 & 3,044 & 3,021 & 3,036 & 3,048 & 3,070 & 3,073 \\
\hline Sub-sector of creative production & 20,113 & 21,115 & 21,596 & 21,611 & 20,984 & 20,885 & 20,774 & 20,812 & 20,809 \\
\hline Programming & 165 & 229 & 282 & 321 & 329 & 342 & 374 & 404 & 418 \\
\hline Publishing & 10,486 & 10,939 & 11,190 & 11,056 & 10,868 & 10,753 & 10,765 & 10,599 & 10,605 \\
\hline Film and TV p & 7,462 & 7,795 & 7,842 & 7,962 & 7,512 & 7,527 & 7,391 & 7,574 & 7,526 \\
\hline Radio and music production & 2,000 & 2,152 & 2,282 & 2,272 & 2,275 & 2,263 & 2,244 & 2,235 & 2,260 \\
\hline Sub-sector of creative services & 54,572 & 58,792 & 61,952 & 63,583 & 64,271 & 64,979 & 65,909 & 66,820 & 68,125 \\
\hline Fashion and design & 5,359 & 6,187 & 7,006 & 7,470 & 7,639 & 7,928 & 8,249 & 8,766 & 9,322 \\
\hline Advertising and $\mathrm{r}$ & 31,232 & 32,521 & 33,648 & 34,176 & 34,443 & 34,698 & 35,244 & 35,505 & 36,145 \\
\hline Architecture and interior design & 17,981 & 20,084 & 21,298 & 21,937 & 22,189 & 22,353 & 22,416 & 22,549 & 22,658 \\
\hline
\end{tabular}

Source: REGON data.

ania $(+0.02 \%)$, and Łódź $(+0.01)$. In turn, a drop was noted in Świętokrzyska Land $(-1.84 \%)$, Lubuska Land $(-1.71 \%)$, Kujavia-Pomerania $(-1.29 \%)$, West Pomerania (-1.04\%), Subcarpathia $(-0.86 \%)$, Podlasie $(-0.74 \%)$, Opole $(-0.49 \%)$, Lublin $(-0.44 \%)$, and Warmia-Mazuria $(-0.04 \%)$.

Changes in the number of entities of the sub-sector of creative services entered into the REGON register in the individual regions over the study period are presented in Table 6 .

Over the study period, all regions showed different growth rates in the number of entities. The highest average rates were noted in Subcarpathia $(+4.11 \%)$, Wielkopolska $(+3.28 \%)$ and Podlasie $(+3.22 \%)$; and the lowest, in West Pomerania $(+1.96 \%)$, Warmia-Mazuria $(+2.09 \%)$ and Opole $(+2.14 \%)$. The sub-sector of creative services is the part of the sector of creative industries where the highest average growth rate was recorded.

Changes in the number of entities of the creative sector by individual sub-sector and area of activity are presented in Table 7.

In the sector of creative industries, the areas showing the highest average growth rates were: programming $(+12.32 \%)$, fashion and design $(+7.17 \%)$, architecture and interior design $(+2.93 \%)$, advertising and related activity $(1.84 \%)$, and radio and music production $(+1.54 \%)$. A fall was only recorded in visual arts $(-1.61 \%)$.

The creative sector embraces the three sub-sectors differing in the legal forms in force, problems related to their functioning, and growth accelerators and inhibitors. Representatives of the crea- tive sector indicate a few significant factors determining its development (Kasprzak 2013: 94):

- Education of members of the creative sector: most universities (schools) educating workers of this sector do not prepare them for economic activity, focusing on the transfer of knowledge from a specific discipline of art.

- Competence of members of the creative sector: often indicated is a lack of skills in areas indispensable for economic activity, such as legal and tax issues, the skill to acquire funds (not only public) as well as the skill to plan the development of an organisation.

- Customer education: factors determining the consumption of cultural services (i.e. products of the creative industry) are not limited to a household's financial status, but also include the level of the cultural education of its members, their actual and expected social status, leisure resources, etc. And those other factors make the demand for products of the creative sector highly unpredictable.

The list of problems facing entities of the creative industry differs little in regional terms. For example, in Kujavia-Pomerania and Pomerania their key problems are: lack of funds for development and daily operation, strong competition, a poor and unpredictable demand, red tape and legal provisions, as well as lack of support from business-environment institutions (Grochowski et al. 2012). The problems indicated by entities from Silesia include, first of all, a limited demand for such services, difficulty with market survival 
resulting from this type of demand and lack of management-related knowledge, as well troubles with financing an entity's current development (Buchholtz et al. 2012). A crucial problem seems to be a low level of cooperation in this sector, which is not conducive to building a wider product offer and ultimately to the development of this industry.

\section{Impact of the creative sector on the Polish economy}

As part of the socio-economic system, the sector of creative industries stimulates the economic development of regions. Its impact on the national economy can be described in terms of three types of effects that it makes: direct, indirect, and induced. Direct effects include:

- Job creation - most entities operating in the creative sector render services to their customers, so the coincidence of the time and place of performance with the time and place of consumption (purchase) characteristic of them means that this sector creates jobs close to consumers, mostly in the country (or region). Moreover, the inability to store cultural services and the often individual nature of a service and the local nature of its provision cause creative-sector workers to be required to possess specific, often high, qualifications.

- Complementarity - the creative sector is complementary to other sectors of the economy, which means that it creates a climate conducive to the development of other areas of the national economy; creative industries usually attract investment in catering, tourism and trade.

- Tax revenues - an actively operating branch of creative industries contributes to more taxes flowing to the central and local budgets, e.g. the visitors' tax, market dues, the real-estate tax, personal income and corporate income taxes, the goods and services tax (VAT).

Indirect effects include the following factors, either non-measurable or very difficult to assess objectively:

- a promotional factor that makes a given area (country or region) distinguishable from other places in the offer addressed to tourists, investors or people looking for a place to live;
- a factor reinforcing locational attractiveness, which enables attracting entities that make use of the creativity potential and look for a wide offer of leisure-related services for their employees;

- a factor activating the community by creating new market niches not only for local entrepreneurs but also for non-profit, e.g. socially oriented, activities;

- a factor revitalising the local urban fabric by stimulating social transformations in selected regions; and

- a socialising factor - addressing part of the offer to endangered groups or those subjected to social exclusion makes possible a gradual reconstruction of the local community.

The third group - induced effects - involves growth in spending caused by an increase in a region's revenues (e.g. wages) resulting from the activity of entities of creative industries. This is due to consumer expenses of those working in this sector and living in the region. An impulse is the financial resource that remains in the region and makes room for further economic activities.

With the effects described above, entities of the creative sector can contribute to the creation of solid foundations for the development of a country and building its competitive advantage in Europe's economy.

\section{Summing up}

The highly diversified sector of creative industries is an important element of the Polish economy, but it requires particular concern and care for its development. The introduction of the market economy and technological progress have greatly boosted its development. Today it includes both large and recognisable entities as well as small ones pursuing a variety of activities.

The opulence of this sector and its strong internal differences are an important factor of building a competitive advantage, but on the other hand they make it difficult to work out a uniform economic policy aimed at its growth. Still, it can be an essential endogenous factor of economic growth. 


\section{References}

Bombol M., 2008. Czas wolny jako kategoria diagnostyczna procesów rozwoju społeczno-gospodarczego (Leisure time as a diagnostic category of socio-economic development). Oficyna Wydawnicza SGH, Warszawa.

Buchholtz S., Kuskowski J., Lewandowski P., Magda I., Ośka M., Pospieszyńska-Burzyńska J., Regulski A., Sekuła E. A., Ślęzak-Tazbir W., Zawistowski J., Zub M., 2012. Analiza potencjatu rozwojowego funkcji metropolitalnych obszarów aglomeracji miejskich województwa ślaskiego będacych ośrodkami wzrostu gospodarczego województwa ślaskiego w kontekście procesów zachodzacych na regionalnym rynku pracy - kultura i przemysty kreatywne (Analysis of the development potential of metropolitan functions of urban agglomerations - centres of the economic growth of the voivodeship of Silesia, in terms of processes taking place on the regional labour market: culture and creative industries). Instytut Badań Strukturalnych, Warszawa.

Dąbrowska A., 2008. Rozwój rynku ustug w Polsce - uwarunkowania i perspektywy (Development of the service market in Poland: determinants and prospects). Oficyna Wydawnicza SGH, Warszawa.

Debord G., 1967. La société du spectacle (The society of the spectacle). Gallimard, Paris.

Department for Culture, Media and Sport, 2001. Creative Industries Mapping Document. London.

Dziennik Ustaw (Official Gazette), 2012. Obwieszczenie Marszałka Sejmu Rzeczypospolitej Polskiej z dnia 24 kwietnia 2012 r. w sprawie ogłoszenia jednolitego tekstu ustawy o staty- styce publicznej (Proclamation of the Marshal of the Polish Sejm of 24 April 2012 on the publication of a consolidated text of the Public Statistics Act), position 591, Warszawa.

Grochowski M., Dudek-Mańkowska S., Fuhrmann M., Zegar T., 2012. Sektor kreatywny w województwach pomorskim $i$ kujawsko-pomorskim - raport $z$ badań (The creative sector in Pomerania and Kujavia-Pomerania: a research report). Agencja Rozwoju Pomorza, Gdańsk.

Janoś-Kresło M., 2002. Ustugi społeczne w procesie przemian systemowych $w$ Polsce (Social services in the process of the systemic transformation in Poland). Oficyna Wydawnicza SGH, Warszawa.

Kasprzak R. 2013. Przemysty kreatywne w Polsce - uwarunkowania i perspektywy (Creative industries in Poland: determinants and prospects). Wydawnictwo Kamon Consulting Warszawa.

Segers K., Huijgh E., 2006. Clarifying the complexity and ambivalence of the cultural industries. Centre for Studies on Media and Culture, Vrije Universiteit Brussel, Working Papers 8, Brussels.

Throsby D., 2001. Economics and culture. Cambridge University Press, Cambridge.

UNCTAD, 2010. Creative economy report 2010: A feasible development option. New York, Geneva.

Urząd Marszałkowski Województwa Małopolskiego (Marshal's Office of Małopolska Voivodeship), 2013. Program strategiczny Dziedzictwo i Przemysty Czasu Wolnego (Strategic programme Heritage and Leisure-Time Industries). Departament Kultury i Dziedzictwa Narodowego oraz Departament Turystyki, Sportu i Promocji Województwa Małopolskiego, Kraków. 